\title{
The role of purpose in life and social support in reducing the risk of workaholism among women in Poland
}

\begin{abstract}
BACKGROUND
Workaholism is related to experiencing high negative emotions, the inability to control them, and poor psychological well-being. One of the possible countermeasures against the risk of workaholism can be purpose in life. According to Frankl and Yalom, the feeling that life has a meaning or purpose prevents an individual from experiencing meaninglessness. Purpose in life is considered to be closely associated with mood and well-being and has been proven to act as a countermeasure against depression.
\end{abstract}

\section{PARTICIPANTS AND PROCEDURE}

The goal of our study was to analyze the relation between workaholism, perception of purpose in life, and social support among women. Two hundred and sixty female professionals took part in the study. They occupied either specialist or managerial positions in their companies, which implies being highly committed to professional roles. Two sociodemographic variables were included in the analysis as significant moderators of the relation studied, namely family status: whether or not women had children, and marital status. We used the following analytical methods: Robinson's Work Addiction Risk Test (WART, adapted from English by K. Wojdylo), the Pur-
pose-in-Life Test developed by Crumbaugh and Maholick, and Schwarzer's and Schulz's Berlin Social Support Scales.

RESULTS

Statistical analysis allowed us to test a model, which proved the existence of a significant relation between "social support" and "purpose in life" variables. The results also indicate a dependency between "purpose in life" and "workaholism" - higher scores in "purpose in life" correspond to lower results in "workaholism". Additionally, "purpose in life" can be considered a partial mediator between "social support" and "workaholism".

\section{CONCLUSIONS}

The direct results prove that social programs aimed at reducing the risk of workaholism by strengthening social support networks can be both effective, e.g. for mothers who work professionally, and ineffective, e.g. for women who do not have children.

\section{KEY WORDS}

social support; women; workaholism; purpose in life; compulsion to work

ORganizations - 1: Institute of Psychology, University of Gdansk, Gdansk, Poland · 2: Institute of Psychology,

Polish Academy of Sciences, Warsaw, Poland

authors' Contribution - A: Study design - B: Data collection - C: Statistical analysis - D: Data interpretation .

E: Manuscript preparation · F: Literature search · G: Funds collection

Corresponding Author - Aleksandra Peplińska, Ph.D., Institute of Psychology, University of Gdansk,

4 Bażyńskiego Str., 80-309 Gdansk, Poland, e-mail: a.peplinska@ug.edu.pl

to Cite this ARTICLE - Peplińska, A., Wojdylo, K., Kosakowska-Berezecka, N., \& Połomski, P. (2015). The role of purpose

in life and social support in reducing the risk of workaholism among women in Poland. Health Psychology Report,

3(4), 326-335. DOI: 10.5114/hpr.2015.50902 


\section{BACKGROUND}

Most researchers stress that being work-driven is one of the basic characteristics of workaholism and define this phenomenon as a disorder originating from the "compulsion or the uncontrollable need to work incessantly" ( $\mathrm{Ng}$, Sorensen, \& Feldman, 2007; Oates, 1971; Shimazu, Bakker, \& Demerouti, 2009; Shimazu, Demerouti, Bakker, Shimada, \& Kawakami, 2011; Spence \& Robbins, 1992), i.e. 1) work-obsession, characterized by self-imposed high standards, 2) an inability to regulate working habits, and 3) neglecting other activities (Killinger, 1991; Naughton, 1987; Oates, 1971; Poppelreuter, 1997; Robinson, 1998; Schaufeli \& Salanova, 2011; Schaufeli, Shimazu, \& Taris, 2009; Schwartz, 1982; van Wijhe, Peeters, Schaufeli, \& Ouweneel, 2012; Wojdylo, 2007, 2010a, 2010b). The results of several studies provide considerable support for the thesis that, essentially, workaholism is derived more from a specific compulsion-based working style rather than from the excessive number of hours an individual spends working (Burke \& Koksal, 2002; Kanai, Wakabayashi, \& Fling, 1996; McMillan, Brady, O’Driscoll, \& Marsh, 2002; Russo \& Waters, 2006).

An increased scientific interest in workaholism has been noted, especially in literature regarding the sources and outcomes of overworking (e.g. Burke, Matthiesen, \& Pallesen, 2006; Ng et al., 2007; Schaufeli, Taris, \& Van Rhenen, 2008). A number of studies have addressed the issue of workaholism from different perspectives and focused on various factors implicated in its origins (Douglas \& Morris, 2006; McGonagle et al., 2013; Wojdylo, 2013; Wojdylo, Baumann, Buczny, Owens, \& Kuhl, 2013; Wojdylo, Baumann, Fischbach, \& Engeser, 2014). Some authors have shed light on the issue by using cultural perspective, deriving workaholism from gender stereotypes. However, the results of studies attempting to encompass the relationship between gender and workaholism are neither completely clear nor conclusive (Burke, 1999, 2000; Harpaz \& Snir, 2003). Women are stereotypically considered to be interdependent and communal, and hence ascribed to the family roles, whereas men are expected to be independent and active breadwinners (Eagly \& Karau, 2002; Heilman, 2001; Rudman \& Glick, 2001; Rudman \& Phelan, 2010).

Numerous studies have shown the pervasiveness of gender stereotypes, which are socially maintained by the very existence of gender roles (Eagly \& Steffen, 1984). Gender stereotypes are strongly embedded in the cultural context and contain both prescriptive and proscriptive indicators of what men and women should and should not do. They are internalized by both genders, who act according to social expectations and take up gender-congruent roles (Burgess \& Borgida, 1999; Kosakowska, 2008; Prentice \& Carranza, 2002; Rudman, Moss-Racusin, Phelan, \& Nauts, 2012). This in turn has a significant influence on an individual's quality of life, since the influence of cultural expectations with regard to gender is wide - spanning from family life to one's career. Looking closely at the careers of men and women, statistics concerning the employment rate in Europe clearly reflect the gender division in the labor market: women, especially those with two children, constitute the group with the lowest employment rate in the EU countries (EU, 2012). The knowledge of gender prescriptions and proscriptions should be an indication of men's higher propensity to overwork and, as a result, being more prone to workaholism than women. Unexpectedly, and contrary to gender stereotypes, most of the evidence accrued so far indicates the opposite tendency: workaholism seems to be a characteristic more typical among women than men (Behson, 2002; Spence \& Robbins, 1992; Wojdylo \& Lewandowska-Walter, 2010). Women are more obsessed with work, feel stronger compulsion to work, experience more work-related stress, and spend more time working than men (Spence \& Robbins, 1992). Results of studies revealed that women and men differ in terms of work addiction: experiencing higher obsession, control/perfectionism and overwork (Wojdylo \& Lewandowska-Walter, 2010). Hence, women are, generally, more often observed to reach higher levels of perfectionism than men and experience higher professional stress (Burke, 1999). The compulsion to be perfect is reflected in the pursuit to effectively fulfill the multiple roles women have to comply with in contemporary societies (Kosakowska \& Petrus, 2006). Since women often face the challenge of "working the double shift", i.e. being active employees and mothers (Kosakowska, Chybicka, \& Kaźmierczak, 2006), they have to manage the burden of balancing work and family life (Chrzan-Dętkoś, Kosakowska-Berezecka, \& Pawlicka, 2011). This often forces them to work irregular hours, e.g. during weekends or lunch hours (Behson, 2002), while achieving normalized standards, which in turn interferes with doing house chores. Gender prescriptions place heavy demands on women to conform to their domestic roles; hence, if they want to follow professional careers, they have to prove they belong in roles stereotypically ascribed to men (Peplińska, Lipowski, \& Nieckarz, 2011; Phelan \& Rudman, 2010; Rudman \& Fairchild, 2004).

Personality factors also play an important role in determining the individual level of workaholism. The compulsion to work is related to a high level of neuroticism (Burke, Matthiesen, \& Pallesen, 2006). Higher work-related stress, high perfectionism, and aversion to delegate are characteristics emblematic of workaholism (Burke, 2000; Burke \& MacDermid, 1999; Spence \& Robbins, 1992), often accompanied
Purpose in life, social support and workaholism 
by high levels of exhaustion and cynicism (Burke \& Matthiesen, 2004). Both clinical and empirical data indicate that being obsessed with work is often related to depression, anxiety and anger (Fassel, 1991; Poppelreuter, 1997; Oates, 1971; Robinson, 1989), inferiority complex, and fear of failure (Poppelreuter, 1997; Pietropinto, 1986; Spence \& Robbins, 1992; Spruell, 1987). A study conducted among Norwegian journalists showed that workaholics experience significantly less positive emotions related to work than work enthusiasts (Burke \& Matthiesen, 2004). Important antecedents of work addiction, explaining approximately $30 \%$ of variance of workaholism, include high negative emotionality and high arousal (Wojdylo, 2005b). Workaholics do not seem to be fully able to regulate their emotional behavior: being obsessively involved with work constitutes a strategy to minimize potentially negative emotions and maximizing the arousal mobilizing an individual to work (van Wijhe et al., 2012; Wojdylo, 2005b, 2007). Additionally, most of the results suggest that workaholism is also related to poorer psychological and physical well-being (Andreassen, Ursin, \& Eriksen, 2007; Burke \& Matthiesen, 2004; Spence \& Robbins, 1992).

Studies concerning the relation between workfamily balance and workaholism visibly suggest an inverse relation between workaholism and the quality of intimate relationships workaholics establish: workaholism is often positively related to work-family conflict (Bakker, Demerouti, \& Burke, 2009; Bonebright, Clay, \& Ankenmann, 2000). Employees with a compulsive propensity to spend an extremely high percentage of their time working professionally neglected their domestic obligations and the relationship with their partner and eventually offered less support to their partners, which resulted in reduced relationship satisfaction (Peplińska \& Rostowska, 2013). Hence, romantic relationships maintained by workaholics are of low quality due to their visible difficulties in developing and maintaining intimate interpersonal relationships (Berglas, 2004; Porter, 1996; Robinson, 1998; Robinson \& Post, 1995, 1997). The origins of this extensive urge to work can be found in the need to avoid emotional life and in fear of being intimate (Bal \& Kooij, 2010; Balducci, Schaufeli, \& Fraccaroli, 2011; Minirth, Meier, Wichern, Brewer, \& Skipper, 1981). Recent studies have shown that workaholics neglect all areas of life, apart from work, and have a tendency to avoid private life and intimacy (Berglas, 2004; Porter, 1996).

Based on data indicating that workaholics have poor relationships and offer little support to their partners, the low level of social support they receive themselves can be expected (Bonebright et al., 2000). Furthermore, workaholism is related to experiencing high negative emotions, the inability to control them, and poor psychological well-being. According to Frankl (1959) and Yalom (1980), the feeling that life has a meaning or purpose prevents an individual from experiencing meaninglessness. Purpose in life is considered to be closely associated with mood and well-being (King, Hicks, Krull, \& Del Gaiso, 2006; Guzewicz, Steuden \& Szymona-Pałkowska, 2014) and has been proven to act as a countermeasure against depression (Hedberg, Gustafson, Alex, \& Brulin, 2010). This allows us to assume that workaholism is related to low purpose in life.

In this study, we have focused on the relationship between workaholism, purpose in life, and social support as experienced by the female population. The goal of our study was to shed light on the impact of gender roles on the level of workaholism, and to examine how the tendency of female professionals to obsessive/pathological overwork is related to their purpose in life and the social support they receive. Furthermore, considering typical female roles of being a mother and a wife, we have analyzed how these two variables relate to workaholism among female professionals manifesting high pathological/obsessive work involvement.

\section{PARTICIPANTS AND PROCEDURE}

\section{PARTICIPANTS}

The study was conducted among 260 highly qualified and educated female professionals occupying either managerial or specialist positions. Our target participant group was selected upon certain criteria. They were women for whom being highly involved in developing a professional career was of key importance, since we assumed that this might influence women's non-professional life and lead to work-life conflict (Lipińska-Grobelny, 2014). The burden of mediating between private life and work life is particularly visible when a woman is fulfilling typical family roles, such as mother, wife, etc. Hence, our study was carried out among women between 30 and 40 years of age. As many as $51.50 \%$ of the study population were in a stable relationship and $49.20 \%$ had at least one child. The participants were divided into four groups: 1) single childless women $(n=65), 2)$ single women with children $(n=61), 3)$ childless women in a relationship ( $n=67)$, and 4) women in a relationship, with children $(n=67)$.

\section{PROCEDURE}

The study was carried out between 2012 and 2013 among employees of such private sector branches as IT, commerce, and the fuel industry. The study group was selected from a population of female managers or specialists occupying positions requiring high commitment to work (minimum of 10-12 working 
hours, also during weekends and at home). In order to collect data among female professionals highly devoted to their career, HR departments of several companies were involved in the study and distributed questionnaires among women meeting the selection criteria. The subjects were informed that participation in the study is anonymous and fully voluntary and the results are used for scientific purposes only.

\section{MEASURES}

Workaholism. The level of workaholism was measured with the Work Addiction Risk Test (WART) (Robinson \& Phillips, 1995), in the Polish adaptation by Wojdylo (2005a). This questionnaire allows one to measure the general level of workaholism (Cronbach's $\alpha=.87$ ) and, additionally, its five dimensions: Obsession/Compulsion, Emotional arousal/Perfectionism, Overwork, Goal Orientation, and Self-Worth (Wojdylo, 2005a).

Social support. The Berlin Social Support Scale (BSSS) (Schulz \& Schwarzer, 2003) was used, in the Polish adaptation by Łuszczyńska, Kowalska, Mazurkiewicz, and Schwarzer (2006), in order to analyze the relation between workaholism and social support. The scale allows one to determine the general level of social support $(\alpha=.80)$, along with five independent dimensions: perceived support $(\alpha=.90)$, the need for support $(\alpha=.74)$, seeking support ( $\alpha=.77)$, support actively received $(\alpha=.85)$, and protective support $(\alpha=.80)$.

Purpose in Life. The purpose in life was measured with the Purpose in Life Test (Crumbaugh \& Maholick, 1964), in the Polish adaptation by Płużek (Popielski, 1987). The questionnaire is based on Frankl's concept of neogenic neurosis (Frankl, 1972 in: Popielski, 1987), and allows one to determine to what extent an individual is aware of the sense of his/her life and its goals, affirmation, self-evaluation, evaluation of one's life, sense of responsibility and freedom, and the attitude to death and suicide (Cronbach's $\alpha$ between .64 and .70, depending on the population; in our study between .75 and .79).

\section{PART I - RELATIONSHIP BETWEEN PURPOSE IN LIFE, SOCIAL SUPPORT AND WORKAHOLISM AMONG WOMEN}

The preliminary stage of the study was aimed at verifying the significance of the relation between purpose in life, social support, and workaholism in a group of female professionals. We also investigated the possible correlation between the level of workaholism and women's marital and family status. We focused on the potential relationship and mediators between the following variables: purpose in life, social support, and workaholism. Considering how gender stereotypes strongly influence the situation of women, we have assumed that single childless women would be the group most likely to develop workaholism (Hypothesis 1). Being self-reliant and obsessed with one's work is strongly related to lower life satisfaction and low social support and, thus, results in an individual working in order to avoid private life and intimacy (Berglas, 2004; Porter, 1996). Therefore, according to the recent results of studies (Andreassen et al., 2007; Burke \& Matthiesen, 2004; Spence \& Robbins, 1992), we expect a significant inverse relationship between purpose in life, social support, and workaholism among women. The propensity for workaholism can be accompanied by experiencing feelings of low purpose in life and the lack of social support irrespective of the groups differentiated in this study (Hypothesis 2). Further, it can be assumed that this correlation will be the strongest in the case of single childless women (Hypothesis 3) (Berglas, 2004; Minirth et al., 1981; Porter, 1996), and weakest in the group of women in relationships with children.

\section{RESULTS}

Results from the four study groups were submitted to one-way ANOVA (using the Tukey post-hoc test), which illustrated that they differ significantly only with regard to obsession $(F=3.07, p=.028)$. Single and childless women scored the highest in the work-obsession subscale $(M=13.43)$, while single women with children had the lowest score $(M=11.89)$. For the other two groups, the score equaled 12.09 and 12.22 in relationship with children and childless in relationship, respectively (Table 1 ).

The results of correlational analysis showed a significant inverse relationship between purpose in life among women and their addiction to work $(r=-.46$, $p=.012)$, as well as an inverse relationship between social support and workaholism $(r=-.45, p=.013)$.

\section{Table 1}

Mean score of "obsession with work" among four groups: childless single women, single women with children, women in relationship without children, women in relationship with children - Tukey test $(F=3.07, p=.031)$

\begin{tabular}{lccc}
\hline \multicolumn{1}{c}{ Group } & $n$ & \multicolumn{2}{c}{$\alpha=.05$} \\
\cline { 3 - 4 } & & 1 & 2 \\
\hline Single with children & 61 & 11.89 & \\
In relationship, with children & 67 & 12.09 & 12.09 \\
Childless in relationship & 67 & 12.22 & 12.22 \\
Single childless & 65 & & 13.43 \\
\hline
\end{tabular}

Purpose in life, social support and workaholism 
When marital status and having children were taken into consideration, similar results were obtained, both in general and factorial scores for purpose in life and social support. Correlational analysis of purpose in life and workaholism yielded the following results: in a relationship with children $(r=-.35, p=.015)$, single with children $(r=-.73, p=.001)$, childless in a relationship $(r=-.37, p=.011)$, and single childless $(r=-.47, p=.001)$. The following correlations were obtained between social support and workaholism in the four groups: in a relationship with children $(r=-.18, p=.053)$, single with children $(r=-.83$, $p=.001)$, childless in a relationship $(r=-.40, p=.013)$, and single childless $(r=-.52, p=.001)$.

In the group of women in a relationship with children, no significant relation between social support and workaholism was observed.

\section{DISCUSSION}

The results of our study do not unambiguously confirm the hypothesis that single childless women are at the highest risk of workaholism due to compensation for their less satisfactory private life with devotion to work (Hypothesis 1). Nevertheless, the significant differences in work obsession among the studied population suggest that childless single women could constitute the group of the highest risk of being addicted to work. On the other hand, the group with the lowest risk of developing work obsession were single women with children. Hence, having children and having a partner seem to be important variables influencing the level of workaholism and its relation to purpose in life and social support.

The negative relationships between: 1) purpose in life and workaholism, and 2) social support and workaholism among female professionals were confirmed. The analysis of results adjusted for women's marital and family status has also proven an analogi-

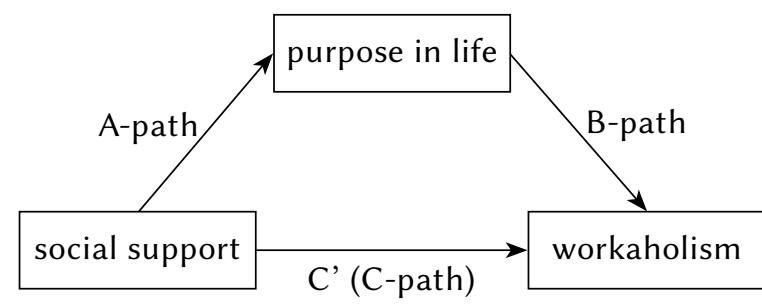

Figure 1. Purpose in life as a mediator between social support and workaholism among women. cal relation for all groups. Both the overall score and the particular scores in all subscales of social support and purpose in life were inversely related to the level of workaholism.

\section{PART II - MEDIATING ROLE OF PURPOSE IN LIFE}

In the second stage of analysis the role of having a partner and children was analyzed within the relationship between workaholism, purpose in life and social support.

In order to carry out a more detailed analysis of the obtained results, we assumed that purpose in life acts as a mediator between social support and workaholism among women (Hypothesis 4) and, furthermore, having children and being in a relationship moderate the relation between purpose in life, social support, and workaholism (Hypothesis 5).

\section{RESULTS}

In order to answer the questions about the mediating role purpose in life plays between social support and workaholism within our study groups, we conducted a mediation analysis as proposed by Preacher and Hayes (2008). This model assumes the comparison of an indirect relationship between independent and dependent variables when a potential mediator is introduced into the model (Fig. 1). In order to verify the hypothesis concerning the moderated mediation model, a nested SEM model analysis was adopted (Preacher \& Hayes, 2008).

In the first step the mediation model for all women groups was analyzed. The assumed null model turned out to be well fitted to the data (Table 2). The study results revealed (Fig. 2) that social support was inversely related to workaholism $(B=-.45, p=.001)$ and positively related to purpose in life $(B=.56$, $p=.001)$. Furthermore, the results showed that purpose in life was inversely related to workaholism $(B=-.30, p=.014)$. Because both the A-path and B-path were significant, mediation analyses were tested using the bootstrapping method with bias-corrected confidence estimates (Preacher \& Hayes, 2008). In this study, the $95 \%$ confidence interval (CI) of the indirect effects was obtained with 1000 bootstrap resamples. Results of the mediation analysis (Table 3) confirmed the mediating role of purpose in life on social support and workaholism for all four study

Table 2

Indicators of global model fitting

\begin{tabular}{cccc}
\hline$\chi^{2}(9)=16.09, p=.651$ & RMSEA $=0.08$ & GFI $=0.92$ & AGFI $=0.89$ \\
\hline Note. RMSEA - root mean square error of approximation; GFI - goodness of fit index; AGFI - adjusted goodness of fit index
\end{tabular}


groups $(B=-.17, \mathrm{CI}-.09$ to $-.24, p=.001)$. Moreover, the research results revealed that social support exerts a significant direct effect on workaholism $(B=-.28, p=.001)$ when controlling for purpose in life; this points to its partial mediation effect. Hence, the relationship between social support and workaholism is partially influenced by purpose in life among the female population. In conclusion, the level of workaholism among women depends not only on the social support, but also on purpose in life.

In the next step of analysis the model was also tested between different clusters of two variables, $b e$ ing in a relationship and having children, as potential moderators of the relationship between workaholism, purpose in life and social support. The following models were compared: the model for all women groups (Model 1), single women (Model 2) and women with children (Model 3). Contrast analysis indicated that alternative models, for both single women in comparison with women in relationships, and women with children and childless women, are different from the null model assuming equal variances for all groups. Single women $\left(\chi^{2}(3)=9.23, p=.012\right)$ show different effect of relations between variables analyzed in the mediation model in comparison with women living in a relationship, women with children and childless women $\left(\chi^{2}(3)=9.12, p=.009\right)$. This allowed us to compare models for combined groups: the model for single women with children (Model 4, Table 4) in comparison with other groups of women. The obtained results allow us to conclude that the assumed model of mediation is the most accurate in reflecting the relationships between variables among single women with children in comparison to other

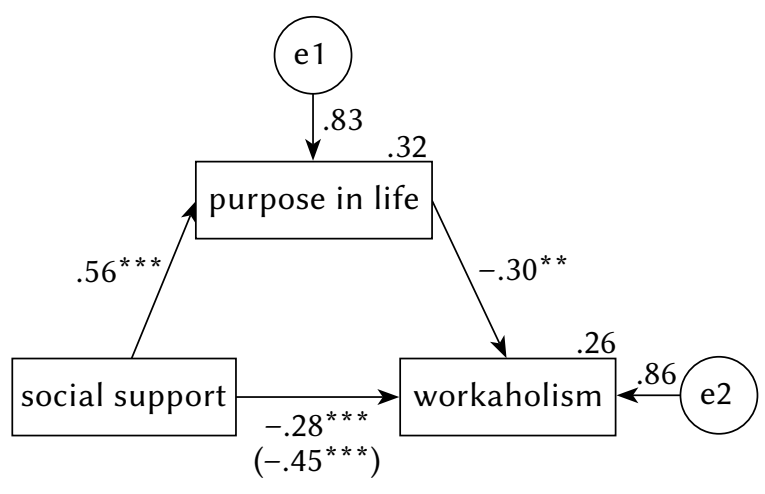

Note. ${ }^{* *} p<.01,{ }^{* *} p<.001$.

Figure 2. Output path diagram of the mediating role of purpose in life in social support and workaholism among women.

groups $\left(\chi^{2}(6)=10.15, p=.001\right.$, Model 4$)$. Hence being in a relationship and having children moderates the relationship between social support, workaholism and purpose in life. Direct and partial mediation effects in the relationship between variables of models for single women with children are presented in Figure 3 and Table 5.

\section{DISCUSSION}

The analysis of our findings confirmed that purpose in life constitutes a significant mediator in the relation between social support and workaholism. Hence, a significant negative relation between the sense of being socially supported and compulsion to work can be established. The impact of this relation
Purpose in life, social support and workaholism

Table 3

Social support, workaholism and their relations with purpose in life among women

\begin{tabular}{|c|c|c|c|c|}
\hline & & \multicolumn{3}{|c|}{ Indirect effect } \\
\hline Estimator (Social Support) & & $-.17^{* * *}$ & $-.28^{* *}$ & $-.45^{* * *}$ \\
\hline \multirow{2}{*}{$95 \%$ confidence intervals } & Lower limit & -.24 & -.41 & -.54 \\
\hline & Upper limit & -.09 & -.16 & -.36 \\
\hline
\end{tabular}

Note. ${ }^{* *} p<.01,{ }^{* * *} p<.001$.

Table 4

Comparison of tested models

\begin{tabular}{lccccc}
\hline \multicolumn{1}{c}{ Model } & $\chi^{2}$ & $d f$ & $p$ & $\chi^{2}$ of change & $p$ of change \\
\hline Model 1 & 16.45 & 9 & .048 & 16.45 & .038 \\
Model 2 & 7.23 & 3 & .065 & 9.23 & .012 \\
Model 3 & 7.33 & 3 & .062 & 9.12 & .011 \\
Model 4 & 6.30 & 6 & .389 & 10.15 & .007 \\
\hline
\end{tabular}

Note. Model 1 (null): equal variance assumed for all groups. Model 2: equal variance assumed for single women and women in relationship. Model 3: equal variance assumed for women with children and childless women. Model 4: equal variance assumed in comparison between single women and other groups. 


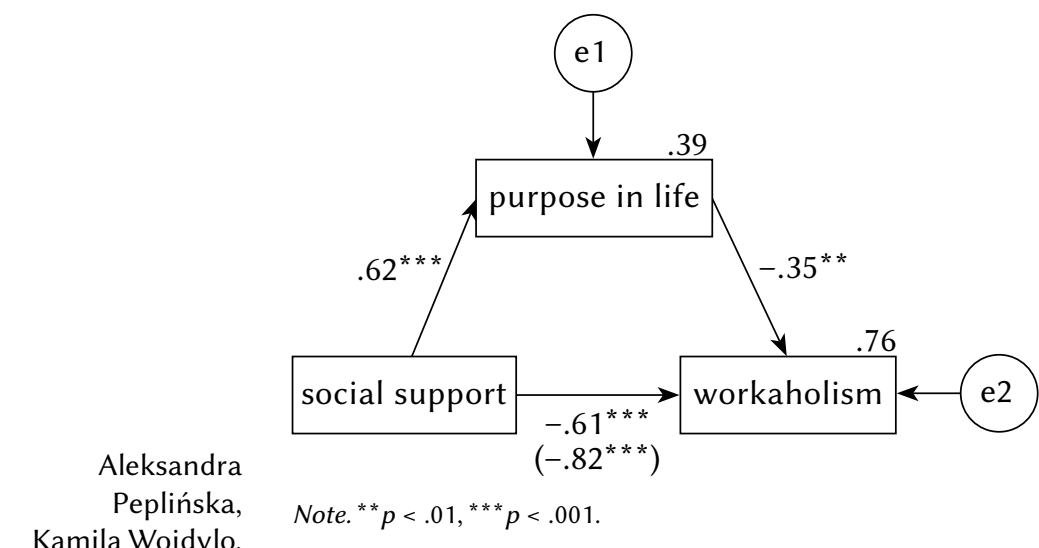

Kamila Wojdylo,

Natasza

Kosakowska-

Berezecka,

Piotr Połomski

Figure 3. Output path diagram of social support and workaholism with the mediating role of purpose in life among single women with children. is even stronger when considering purpose in life. A positive relation between women's purpose in life and the sense of being socially supported can function as a necessary buffer, either reducing or preventing the risk of addicting oneself to work.

When additional variables were introduced, the moderated mediating model for single women with children complied with the data. The model illustrates that the relation between social support, purpose in life, and workaholism is especially significant and robust among single mothers. Therefore, it can be concluded that single women receiving appropriate support from both close relatives and responsible institutions, and experiencing high purpose in life, which stems from having children, have the lowest risk of developing work addiction. Our conclusion corresponds strongly to the data indicating that this group shows the lowest obsession with work as compared with single childless women.

\section{CONCLUSIONS}

The results of our study emphasize that two factors, being in a relationship and having children, are significantly related to work obsession. Single childless women constituted the group the most obsessed with work, whereas single women with children constituted the group the least obsessed with work. Therefore, having the status of being single and childless can increase the propensity to be a workaholic.
However, it should be stressed that the obtained results indicate that both purpose in life and social support are inversely related to being addicted to work. These two variables can constitute a certain buffer against workaholism. Women who are supported by their partners, family and friends, and still have strong purpose in life, are less prone to use compensatory mechanisms of being singularly focused on their professional careers. As a result, they are at a lower risk of becoming workaholics.

Additionally, purpose in life turned out to be a significant mediator of the relation between social support and workaholism. Being in a relationship and having children change the relation between purpose in life and social support. Both variables (being in a relationship and having children) were important moderators of the relations described above. However, a significant model of moderated mediation of purpose in life on social support and workaholism was only observed for single women with children, who are at the lowest risk of developing workaholism. Our findings revealed that this group receives the greatest social support and experiences strong purpose in life due to the fact of having children two factors which effectively prevent single mothers from suffering from workaholism.

Thus, our results support the conclusions drawn from many studies concerning work-family balance, illustrating that fulfilling multiple roles - being a source of social support, affirming one's successes and talents - can have significant psychological benefits for an individual (e.g. Barnett \& Hyde, 2001; Barnett, Marshall, \& Pleck, 1992; Marks, 1977; Thoits, 1983; Pietromonaco, Manis, \& Frohardt-Lane, 1984, in: Baruch, Biener, \& Barnett, 1987; Lu, 2000). Our conclusion is opposed by the view that the relation between work and family constitutes a zero-sum game (Parasuraman \& Greenhaus, 2002), i.e. if a woman devotes herself to her professional career, she will not be equally effective in performing her family roles. Importantly, receiving support from the partner and sharing household duties is one of the necessary conditions for a woman to achieve worklife balance and reduce the risk of developing workaholism (Chrzan-Dętkoś et al., 2011). However, more studies are necessary to shed light on the different origins of workaholism among men and women.

Table 5

Social support and workaholism - the mediating role of purpose in life among single women with children

\begin{tabular}{llccc}
\hline & & \multicolumn{3}{c}{ Indirect effect } \\
\hline \multirow{2}{*}{ Estimator (Social Support) } & & $-.22^{* * *}$ & $-.61^{* * *}$ & $-.83^{* * *}$ \\
& & -.32 & -.75 & -.89 \\
$95 \%$ confidence intervals & Lower limit & -.12 & -.35 & -.71 \\
\hline
\end{tabular}

Note. ${ }^{* *} p<.01,{ }^{* * *} p<.001$. 


\section{REFERENCES}

Andreassen, C. S., Ursin, H., \& Eriksen, H. R. (2007). The relationship between strong motivation to work, "workaholism", and health. Psychology \& Health, 22, 615-629.

Bakker, A. B., Demerouti, E., \& Burke, R. (2009). Workaholism and relationship quality: a spillover-crossover perspective. Journal of Occupational Health Psychology, 14, 23-33.

Bal, P. M., \& Kooij, D. (2010). The relations between work centrality, psychological contracts, and job attitudes: the influence of age. European Journal of Work and Organizational Psychology, 20, 497-523.

Balducci, C., Schaufeli, W. B., \& Fraccaroli, F. (2011). The job demands-resources model and counterproductive work behaviour: the role of job-related affect. European Journal of Work and Organizational Psychology, 20, 467-496.

Barnett, R. C., \& Hyde, J. S. (2001). Women, men, work, and family. an expansionist theory. American Psychologist, 56, 781-796.

Barnett, R. C., Marshall, N. L., \& Pleck, J. H. (1992). Men's multiple roles and their relationship to men's psychological distress. Journal of Marriage and Family, 54, 358-367.

Baruch, G. K., Biener, L., \& Barnett, R. C. (1987). Women and gender in research on work and family stress. American Psychologist, 42, 130-136.

Behson, S. J. (2002). Coping with family-to-work conflict: the role of informal work accommodations to family. Journal of Occupational Health Psychology, 7, 324-341.

Berglas, S. (2004). Treating workaholism. In: R. H. Coombs (ed.), Handbook of addictive disorders (pp. 383-407). New Jersey: John Wiley and Sons.

Bonebright, C. A., Clay, D. L., \& Ankenmann, R. D. (2000). The relationship of workaholism with work-life conflict, life satisfaction, and purpose in life. Journal of Counseling Psychology, 47, 469-477.

Burgess, D., \& Borgida, E. (1999). Who women are, who women should be: Descriptive and prescriptive gender stereotyping in sex discrimination. Psychology, Public Policy, and Law, 5, 665-692.

Burke, R. J. (1999). Workaholism in organizations: gender fifferences. Sex Roles, 41, 333-345.

Burke, R. J. (2000). Workaholism in organizations: the role of personal beliefs and fears. Anxiety, Stress \& Coping, 13, 53-64.

Burke, R. J., \& Koksal, H. (2002). Workaholism among a sample of Turkish managers and professionals: an exploratory study. Psychological Reports, 91, 60-68.

Burke, R. J., \& MacDermid, G. (1999). Are workaholics job satisfied and successful in their careers? Career Development International, 4, 277-282.

Burke, R. J., \& Matthiesen, S. (2004). Workaholism among Norwegian journalists: antecedents and consequences. Stress and Health, 20, 301-308.
Burke, R. J., Matthiesen, S., \& Pallesen, S. (2006). Workaholism, organizational life and well-being of Norwegian nursing staff. Career Development International, 11, 463-477.

Chrzan-Dętkoś, M., Kosakowska-Berezecka, N., \& Pawlicka, P. (2011). Women, men and second shift - psychological determinants of worklife balance. Polish Journal of Social Sciences, 6, 123-140.

Crumbaugh, J. C., \& Maholick, L. T. (1964). An experimental study in existentialism: the psychometric approach to Frankl's concept of noogenic neurosis. Journal of Clinical Psychology, 20, 589-596.

Douglas, E. J., \& Morris, R. J. (2006). Workaholic, or just hard worker? Career Development International, 11, 394-417.

Eagly, A. H., \& Karau, S. J. (2002). Role congruity theory of prejudice toward female leaders. Psychological Review, 109, 573-598.

Eagly, A. H., \& Steffen, V. J. (1984). Gender stereotypes stem from the distribution of women and men into social roles. Journal of Personality and Social Psychology, 4, 735-754.

EU (2012). The EU report on the role of men in gender equality. Available at http://ec.europa.eu/justice/ gender-equality/files/gender_pay_gap/130424_final_report_role_of_men_en.pdf

Fassel, D. (1991). Wir arbeiten uns noch zu Tode [We work ourselves to death]. München: Kösel.

Frankl, V. (1959). Man's search for meaning. London: Hodder \& Stoughton.

Frankl, V. (1972). Homo patiens. Warszawa: PAX.

Guzewicz, M., Steuden, S., \& Szymona-Pałkowska, K. (2014). Changes in the perception of self-image and the sense of purpose and meaning in life, among women who lost their child before birth. Health Psychology Report, 2, 162-175.

Harpaz, I., \& Snir, R. (2003). Workaholism: its definition and nature. Human Relations, 56, 291-319.

Hedberg, P., Gustafson, Y., Alex, L., \& Brulin, C. (2010). Depression in relation to purpose in life among a very old population: a five-year follow-up study. Aging \& Mental Health, 14, 757-763.

Heilman, M. E. (2001). Description and prescription: how gender stereotypes prevent women's ascent up the organizational ladder. Journal of Social Issues, 57, 657-674.

Kanai, A., Wakabayashi, M., \& Fling, S. (1996). Workaholism among employees in Japanese corporations: an examination based on the Japanese version of the Workaholism Scales. Japanese Psychological Research, 38, 192-203.

Killinger, B. (1991). Workaholics: the respectable addicts. New York: Simon and Schuster.

King, L. A., Hicks, J. A., Krull, J. L., \& Del Gaiso, A. K. (2006). Positive affect and the experience of meaning in life. Journal of Personality and Social Psychology, 90, 179-196.
Purpose in life, social support and workaholism 
Kosakowska, N. (2008). Identity, self-construal and gender role perception. In: A. Chybicka \& M. Kaźmierczak (eds.), Appreciating diversity - gender and cultural issues (pp. 31-54). Kraków: Oficyna Wydawnicza Impuls.

Kosakowska, N., Chybicka, A., \& Kaźmierczak, M. (2006). Women's dual shift - women's quality of life in dual-career marriages. Science Meets Reality, Central European Center for Women and Youth in Science. Conference proceedings online. http:// www.cecwys.org/prilohy/9c841695/Kosakowska\%20et\%20al.pdf

Aleksandra

Peplińska,

Kamila Wojdylo, Natasza

Kosakowska-

Berezecka,

Piotr Połomski

Kosakowska, N., \& Petrus, P. (2006). Kobieta na dwóch etatach - funkcjonowanie kobiet w małżeństwach dwu karier [Woman and her second shift - functioning of women in dual - careers couples]. Psychologia Rozwojowa, 11, 163-174.
Lipińska-Grobelny, A. (2014). Psychological determinants of portfolio workers' satisfaction with life. Health Psychology Report, 2, 280-290.

Lu, L. (2000). Gender and conjugal differences in happiness. Journal of Social Psychology, 140, 132-141.

Łuszczyńska, A., Kowalska, M., Mazurkiewicz, M., \& Schwarzer, R. (2006). Berlińskie Skale Wsparcia Społecznego (BSSS): wyniki wstępnych badań nad adaptacją skal i ich własnościami psychometrycznymi [Berliner Social Support Scales (BSSS): preliminary results of research on the adaptation of scales and their psychometric properties]. Studia Psychologiczne, 44, 17-27.

Marks, S. (1977). Multiple roles and role strain: some notes on human energy, time, and commitment. American Sociological Review, 42, 921-936.

McGonagle, A. K., Barnes-Farrell, J. L., Di Milia, L., Fischer, F. M., Hobbs, B., Kaliterna, L., IskraGolec, I., \& Smith, L. (2013). Demands, resources, and work ability: A cross-national examination of health care workers. European Journal of Work and Organizational Psychology, 23, 1-17.

McMillan, L. H. W., Brady, E. C., O’Driscoll, M. P., \& Marsh, N. V. (2002). A multifaceted validation study of Spence and Robbins' (1992) Workaholism Battery. Journal of Occupational and Organizational Psychology, 75, 357-368.

Minirth, F., Meier, P., Wichern, F., Brewer, B., \& Skipper, S. (1981). The workaholic and his family: an inside look. Grand Rapids, MI: Baker Book House.

Naughton, T. J. (1987). A conceptual view of workaholism and implications for career counseling and research. The Career Development Quarterly, 35, 180-187.

Ng, T. W. H., Sorensen, K. L., \& Feldman, D. C. (2007). Dimensions, antecedents, and consequences of workaholism: a conceptual integration and extension. Journal of Organizational Behavior, 28, 111-136.

Oates, W. (1971). Confession of a workaholic. New York: Abingdon.

Parasuraman, S., \& Greenhaus, J. H. (2002). Toward reducing some critical gaps in work-family re- search. Human Resource Management Review, 12, 299-312.

Peplińska, A., Lipowski, M., \& Nieckarz, Z. (2011). Career and professional development - challenges for employees and modern organizations. Polish Journal of Social Sciences, 6, 75-100.

Peplińska, A., \& Rostowska, T. (2013). Quality of life and relations between work and family. Acta Neuropsychologica, 11, 77-92.

Phelan, J. E., \& Rudman, L. A. (2010). Reactions to ethnic deviance: the role of backlash in racial stereotype maintenance. Journal of Personality and Social Psychology, 99, 265-281.

Pietropinto, A. (1986). The workaholic spouse. Medical Aspects of Human Sexuality, 20, 89-96.

Pietromonaco, P., Manis, J. D., \& Frohardt-Lane, K. (1984). Psychological Consequences of Multiple Social Roles. Ann Arbor, MI: University of Michigan Center for Continuing Education of Women.

Popielski, K. (1987). Testy egzystencjalne: metody badania frustracji egzystencjalnej i nerwicy neogennej [Existential tests: methods of measuring existential frustration and neogenic anxiety]. In: K. Popielski (ed.), Człowiek - pytanie otwarte [Man - the open question] (pp. 237-262). Lublin: RW KUL.

Poppelreuter, S. (1997). Arbeitssucht [Workaholism]. Weinheim: Psychologie Verlags Union.

Porter, G. (1996). Organizational impact of workaholism: suggestions for researching the negative outcomes of excessive work. Journal of Occupational and Health Psychology, 1, 70-84.

Preacher, K. J., \& Hayes, A. F. (2008). Asymptotic and resampling strategies for assessing and comparing indirect effects in multiple mediator models. Behavior Research Methods, 40, 879-891.

Prentice, D. A., \& Carranza, E. (2002). What women and men should be, shouldn't be, are allowed to be, and don't have to be: the contents of prescriptive gender stereotypes. Psychology of Women Quarterly, 26, 269-281.

Robinson, B. E. (1989). Work addiction. Deerfield Beach, FL: Health Communications.

Robinson, B. E. (1998). Chained to the desk : a guidebook for workaholics, their partners and children, and the clinicians who treat them. New York: New York University Press.

Robinson, B. E., \& Phillips, B. (1995). Measuring workaholism: content validity of the Work Addiction Risk Test. Psychological Reports, 77, 657-658.

Robinson, B. E., \& Post, P. (1995). Work addiction as a function of family of origin and its influence on current family functioning. The Family Journal, 3, 200-206.

Robinson, B. E., \& Post, P. (1997). Risk of addiction to work and family functioning. Psychological Reports, 81, 91-95. 
Rudman, L. A., \& Fairchild, K. (2004). Reactions to counterstereotypic behavior: the role of backlash in cultural stereotype maintenance. Journal of Personal and Social Psychology, 87, 157-176.

Rudman, L. A., \& Glick, P. (2001). Prescriptive gender stereotypes and backlash toward agentic women. Journal of Social Issues, 57, 743-762.

Rudman, L. A., Moss-Racusin, C. A., Phelan, J. E., \& Nauts, S. (2012). Status incongruity and backlash effects: defending the gender hierarchy motivates prejudice against female leaders. Journal of Experimental Social Psychology, 48, 165-179.

Rudman, L. A., \& Phelan, J. E. (2010). The effect of priming gender roles on women's implicit gender beliefs and career aspirations. Social Psychology, 41, 192-202.

Russo, J. A., \& Waters, L. E. (2006). Workaholic worker type differences in work-family conflict: the moderating role of supervisor support and flexible work scheduling. Career Development International, 11, 418-439.

Schaufeli, W. B., \& Salanova, M. (2011). Work engagement: on how to better catch a slippery concept. European Journal of Work and Organizational Psychology, 20, 39-46.

Schaufeli, W. B., Shimazu, A., \& Taris, T. W. (2009). Being driven to work excessively hard: The evaluation of a two-factor measure of workaholism in the Netherlands and Japan. Cross-Cultural Research, 43, 320-348.

Schaufeli, W. B., Taris, T. W., \& Van Rhenen, W. (2008). Workaholism, burnout, and work engagement: three of a kind or three different kinds of employee well-being? Applied Psychology, 57, 173-203.

Schulz, U., \& Schwarzer, R. (2003). Soziale Unterstützung bei der Krankhaitsbewältigung: Die Berliner Social Support Skalen (BSSS) [Social support in coping with illness: The Berlin Social Support Scales (BSSS)]. Diagnostica, 49, 73-82.

Schwartz, H. S. (1982). Job involvement as obsession-compulsion. Academy of Management Review, 7, 429-432.

Shimazu, A., Bakker, A. B., \& Demerouti, E. (2009). How job demands affect an intimate partner: a test of the spillover-crossover model in Japan. Journal of Occupational Health, 51, 239-248.

Shimazu, A., Demerouti, E., Bakker, A. B., Shimada, K., \& Kawakami, N. (2011). Workaholism and well-being among Japanese dual-earner couples: a spillover-crossover perspective. Social Science \& Medicine, 73, 399-409.

Spence, J. T., \& Robbins, A. S. (1992). Workaholism: definition, measurement, and preliminary results. Journal of Personality Assessment, 58, 160-178.

Spruell, G. (1987). Work fever. Training and Development Journal, 41, 41-45.

Thoits, P. (1983). Multiple identities and psychological well-being. American Sociological Review, 48, 174-178. van Wijhe, C., Peeters, M., Schaufeli, W., \& Ouweneel, E. (2012). Rise and shine: recovery experiences of workaholic and nonworkaholic employees. European Journal of Work and Organizational Psychology, 22, 476-489.

Wojdylo, K. (2005a). Kwestionariusz Pracoholizmu (WART) - adaptacja narzędzia i wstępna analiza własności psychometrycznych [The Questionnaire of Workaholism (WART) - adaptation and preliminary analysis of psychometric properties]. Nowiny Psychologiczne, 4, 71-84.

Wojdylo, K. (2005b). Pracoholizm. Niektóre wyznaczniki uporczywości działania [Workaholism. Some determinants of work obstinacy] (Doctoral thesis). Warszawa: Szkoła Wyższa Psychologii Społecznej.

Wojdylo, K. (2007). Koncepcja osobowościowych wyznaczników pracoholizmu: weryfikacja założeń w korelacyjnym modelu [A conception of personal determinants of workaholism: verification of assumptions in the correlation model]. Studia Psychologiczne, 45, 53-65.

Wojdylo, K. (2010a). Funkcjonowanie pracoholików w sytuacji zadaniowej [Functioning of workaholics in the task situation]. Przegląd Psychologiczny, 53, 75-98.

Wojdylo, K. (2010b). Pracoholizm. Perspektywa poznawcza [Workaholism. A cognitive perspective]. Warszawa: Wydawnictwo Difin.

Wojdylo, K. (2013). Work craving - teoria uzależnienia od pracy [Work craving - the theory of work addiction]. Nauka, 3, 87-97.

Wojdylo, K., Baumann, N., Buczny, J., Owens, G., \& Kuhl, J. (2013). Work Craving: A Conceptualization and Its Measurement. Basic and Applied Social Psychology, 35, 547-568.

Wojdylo, K., Baumann, N., Fischbach L., \& Engeser, S. (2014). Live to Work or Love to Work: Work Craving, and Work Engagement. PLoS One, 9, 1-7.

Wojdylo, K., \& Lewandowska-Walter, A. (2010). Pracoholizm a płeć i style przywiązaniowe [Workaholism, sex and attachment styles]. In: A. Chybicka \& N. Kosakowska-Berezecka (eds.), W obiektywie ptci. Naukowe i praktyczne inspiracje [In the lens of gender. Theories and applications] (pp. 133149). Kraków: Oficyna Wydawnicza Impuls.

Yalom, I. (1980). Existential psychotherapy. New York: Basic Books.
Purpose in life, social support and workaholism 